\title{
Approach to the Development of Multicultural Education Curriculum in Darul Hikmah Modern Islamic Boarding School Tulungagung, Indonesia
}

\author{
As'aril Muhajir", Ngainun Naim, Agus Zaenul Fitri, Asrop Safi'i \\ State Islamic Institute (IAIN) of Tulungagung, Indonesia
}

Received February 6, 2020; Revised March 24, 2020; Accepted March 28, 2020

Copyright $\bigcirc 2020$ by authors, all rights reserved. Authors agree that this article remains permanently open access under the terms of the Creative Commons Attribution License 4.0 International License

\begin{abstract}
Indonesia is a multicultural country because it has diverse tribes, religions, cultures and races. This multicultural reality is both a wealth and a threat. Multiculturalism is wealth when positively positioned so that it enriches the treasures of life. Conversely, multiculturalism is a threat when it is not managed properly. For this reason, positive awareness and attitudes towards multicultural reality must be built systematically. Educational institutions are instruments that are believed to be able to carry out this task properly. Through the curriculum, students will receive subject matter that can enrich understanding of multicultural reality. This article discusses the approach to develop a multicultural education curriculum at Darul Hikmah Modern Islamic Boarding School, Tulungagung, Indonesia. The development of this multicultural education curriculum is important in building students' understanding to have perspectives that value diversity in various fields of life. The research method used is qualitative and data mining is done by in-depth interviews, observation and documentation. Interviews were conducted with scholars, teachers and students. Observations were made to observe the learning process and implementation of the curriculum from class to class. The documentation is being carried out for the learning process and supporting documents for this research. This study found that there are three approaches used in curriculum development, namely the contribution approach, the additive approach, and the transformation approach. The contribution approach is carried out by meeting students' basic needs. An additive approach is carried out by providing reading books in the library, introducing social life through video, integrating multicultural values and applying them in learning. While the transformation approach is applied to high school students because at this level the students already have a broader perspective so they can analyze the diversity
\end{abstract}

around them.

Keywords Approach, Curriculum Development, Multicultural Education, Boarding School

\section{Introduction}

Islamic boarding school is a typical Indonesian educational institution. Its existence is in line with the history of the growth and development of Islam. Its role is very large in determining the style of Indonesian Islam (Aly, 2015). Islamic boarding school grows and colors the culture of the community (Bustamam-ahmad, 2015).

Islamic boarding school grows and develops in line with the sociological context of the community. In general, there is an impression that Islamic boarding school does not keep up with the times. This kind of impression is not entirely wrong. Not a few Islamic boarding schools survive in conservatism, as if Islamic boarding schools only live with their own world (Rif 'atul, Islamic School, Public, \& Jombang, 2015).

However, today there are also many Islamic boarding schools that have experienced encouraging developments. Many Islamic boarding schools undergo transformation towards a more advanced system. Various improvement efforts were made. The multicultural reality also becomes something internalized through various strategies (Raihani, 2012). The pesantren itself has high multicultural potential in the form of egalitarian, flexible and inclusive attitudes. This potential, if maximally developed, will make pesantren an important part in the transformation of wider community life (Rif 'atul et al., 2015).

Multicultural facts itself in relation to Islamic boarding school can be viewed from external or internal aspects. 
External aspects are related to the facts of Indonesian multicultural life. Indonesia is a country with diverse religious, cultural, political, economic and social (Hasan \& Suwarni, 2012). While internally, there are many Islamic boarding schools whose students have diverse backgrounds Big Islamic boarding schools generally have santri coming from various regions in Indonesia. They come from different tribes. The culture and social life context of each student differ from each other (Aly, 2015). This reality shows that Islamic boarding schools are close to multicultural reality.

In the context of learning, an important aspect in the context of Islamic boarding schools is the curriculum. The function of the curriculum is to design the achievements that have been formulated (Hashim \& Langgulung, 2008). In addition, the curriculum has a function to achieve learning targets that have been arranged within a certain period (Wear \& Castellani, 2000). The main function of the curriculum for Islamic boarding schools is not just as a determinant of the direction of learning but as the main door in facing community challenges. This challenge is increasingly complex with the dynamics of the times (Lukens-Bull, 2017).

There are not many Islamic boarding schools that design curricula that are in line with multicultural needs. Multicultural knowledge, insight, and awareness are mostly hidden in the pesantren culture itself. In fact, if it is made explicit in the form of a curriculum, of course the spirit of multiculturalism will be embedded more strongly in the students.

Indeed there has been a lot of researches related to the relationship between pesantren and multiculturalism (Cahyono, 2017; Faoziah, Mahfudh, \& Ronika, 2016; Kuswandi, 2014; Lubis, Embi, Yunus, Wekke, \& Nordin, 2009; Musyarofah, 2016; Noorhayati, 2017; Saifulah, 2014; , 2014; Syafe'i, 2017). In contrast to various studies that have been conducted, this article discusses the approaches used in the development of a multicultural curriculum at the Darul Hikmah Modern Islamic Boarding School, Tulungagung, Indonesia.

\section{Methods}

This research uses a phenomenological approach. This can be seen from the procedures applied, namely the research procedures that produce descriptive data in the form of speech or writing and the observed behavior of the people (subjects) themselves. The type of research used is field research in which the data acquisition process is in accordance with the target or research problem in the form of complete and profound information about the symptoms that are comprehensive in the field (Bogdan \& Biklen, 2003).

\subsection{Data and Source of Data}

This research uses a qualitative method of case study type. As explained by (Bogdan \& Biklen, 2003), case studies are in-depth studies of certain aspects of the social environment by using a single setting or place for storing data. Data collection in this study was conducted by snowball sampling. The type of data used in this study can be divided into two, namely primary data and secondary data. Sources of data can be divided into four types, namely sources (informants), events or activities, places or locations, and documents (Bowen, 2009).

\subsection{Data Collection Technique}

Data collection in this study uses three techniques, namely: participatory observation (participant observation), in-depth interviews (indept interview), and documentation (documentation).

\subsection{Data Analysis}

Data analysis in this study was carried out since before the researcher entered the field, while in the field, and after completion in the field. In its implementation, data analysis in this study uses several techniques. Data analysis techniques used in this study are based on what was developed by Miles and Huberman, namely data reduction, data display, and verification of data (conclusion drawing / verification) (Miles \& Huberman, 1994).

\subsection{Data Validity Check}

To check the validity of the data is done by using several techniques. The data validity techniques include: degrees of credibility, transferability, dependability, and confirmability (Lincoln, 1985). The reliability and validity of the data are absolutely needed in this study. Therefore, it is necessary to check the validity of the data.

\section{Result and Discussion}

\subsection{Determination of Foundation of Curriculum Development}

The foundation for developing a multicultural education curriculum at Darul Hikmah Modern Islamic Boarding School Tulungagung includes:

\subsubsection{Philosophical Foundation}

Philosophical is one of the curriculum foundations (Pring, 2018). In the context of Indonesian education, curriculum designers make the Pancasila philosophy a philosophical basis in curriculum development (Abdullah, 2007).

This research shows that the philosophical foundation of curriculum development in the Darul Hikmah Modern Islamic Boarding School is Pancasila and the 1945 Constitution. This is in line with Law No. 20 of 2003 
concerning the National Education System.

The results of this study reinforce the theory of George R. Knight who argues that adherents to the philosophy of reconstruction recommend that in designing the curriculum, attention should be paid to civilizations that are not stagnant. Civilization is always changing. It is precisely because of that dynamic that the curriculum must be designed by considerating the changes that occur (Knight, 2001).

Darul Hikmah Islamic Boarding School as an educational institution must be able to be an agent in reconstructing social order in the community. The curriculum compiled contains subjects that can raise students' awareness of social problems and find solutions. Planned subjects are issues related to religion, society, economics, politics, and education. Learning methods that are suitable for this are discussion and problem solving. The flow of reconstruction requires the learning process to take place democratically in the sense of involving all students in the learning process.

\subsubsection{Sociological Foundation}

An important aspect to consider in the preparation of the curriculum is the sociological aspect. This aspect is important to be considered so that the curriculum is arranged in accordance with the context of community needs. Curriculums prepared by ignoring sociological aspects will lose relevance to the needs of the community. (Lynch, 2017)

In the context of multicultural education, determining the sociological foundation is very important. The benchmark that curriculum designers should consider is the diverse surroundings. The diversity in question is the diversity of religions in the surrounding environment, the diversity of tribes and races, changes in lifestyle values, and various sociological aspects that develop in society. Designers of multicultural education curricula must be able to ensure that Islamic boarding schools pay attention to aspects of existing cultural diversity. Attention to these matters enables curriculum designs to be made on target.

The results of this study strengthen the theory of James A. Beane, et.all, who argues that curriculum development must consider the development of technology, family structure, community development, cultural diversity and pluralism, and lifestyle values that change (Beane, 2015).

\subsubsection{Psychological Foundation}

Education has a close relationship with psychology. Education deals with students, including behavior in various forms. Changes in behavior for the better are important aspects to be achieved in the learning process. Related to curriculum development, there are two related psychology fields, namely developmental psychology and learning psychology. Developmental psychology studies human beings who continue to develop throughout their ages. Every development requires an appropriate curriculum design. While learning psychology is related to the nature of learning, learning theory, and various aspects of individual behavior related to learning (Bahri, 2017). Determination of the psychological foundation of the development of multicultural education curriculum in Darul Hikmah Modern Islamic Boarding School Tulungagung is based on learning activities in Islamic boarding schools.

The results of this study reinforce the theory of Nana Syaodih Sukmadinata, this basic attention, because in the educational process, is a process that contains an interaction. This interaction process is an interaction that is an interaction between individuals. Interaction between individuals is an interaction that occurs between students and teachers based on development, socio-cultural background, and other factors that are brought from birth (Sukmadinata, 2006).

\subsection{Multicultural Education Curriculum Development Approach}

\subsubsection{Contribution Approach}

The contribution approach in developing a multicultural education curriculum at Darul Hikmah Modern Islamic Boarding School is done in various ways, namely teaching the five souls that are implanted into the souls of the students. The five souls are: (1) sincerity. Darul Hikmah Modern Islamic Boarding School has a sincere spirit in the scholars and students in learning. (2) the soul of simplicity. Simple means that students accept themselves in all circumstances. (3) self-reliant soul, which is independent in living life while in boarding school. (4) have the soul of ukhuwah islamiyah. This soul promotes brotherhood and togetherness that can strengthen the brotherhood. When this soul grows within the students it will have implications for the growth of the spirit of unity in his life, even after graduating from the Islamic boarding school. (5) has a free soul in thinking and doing. The students are free to determine and choose their path.

\subsubsection{Additive Approach}

The additive approach is carried out in Darul Hikmah Modern Islamic Boarding School by providing books in the library, introducing social life through various media, integrating multicultural values and applying them in learning. The substance of this approach is how the students have extensive knowledge about heterogeneous life.

This approach also seeks to build a sense of interest in diversity. This interest becomes a capital for learning and a positive attitude towards differences in religion, culture, ethnicity, and other various differences. The students eventually become inclusive, easy to accept differences, tolerant, and respect for diversity. This kind of attitude also makes it easier for students to interact with new or complex environments. The implementation of this additive 
approach makes students have a passion to keep learning and knowing about complex things.

\subsubsection{Transformation Approach}

The transformation approach to the development of the multicultural education curriculum at Darul Hikmah Modern Islamic Boarding School was carried out for students who study in Islamic high school. At this stage, the students already have a fairly broad perspective. Their thinking is enough to understand the phenomenon objectively. They have been able to analyze the phenomenon of diversity around them. The ability of this analysis is important because it will determine the perspective of reality (Liberna, 2015).

At the implementation level, the teacher who teaches at Darul Hikmah Modern Islamic Boarding School encourages the students to form discussion groups. Discussions are useful in building students' critical abilities, honing analytical skills, and broadening perspectives (Dunne \& Martin, 2006).

The learning model with a transformation approach in this curriculum allows students to help each other in different religious activities. It also accustoms students to be able to accept the diversity, weaknesses and strengths of the phenomena encountered. The transformation approach to multicultural education curriculum development is applied to students of the secondary level because they already have a broader perspective. The students can already analyze the diversity around them. In themselves, it has become a matter of course about diversity so that they can analyze phenomena and determine attitudes appreciatively and constructively.

\section{Discussion}

The results of this study strengthen the theory of James A. Banks approach related to the curriculum.

\subsection{The Contributions Approach}

The curriculum has an important contribution to life locally and nationally. The curriculum with this contribution approach is a curriculum in which there are material national heroes. Insights about heroes are very important because heroes have very diverse backgrounds. It is at this point that the contribution approach plays an important role.

\subsection{Additive Approach}

The curriculum in the additive approach is a curriculum that contains additional material. In this additive approach it is often complemented by books, modules or subject areas of the curriculum without substantially changing it. Each teacher has a book or a module to use as a basis for learning.

\subsection{The Transformation Approach}

The approach is a curriculum development approach that is different from the previous approach, namely the contribution approach and additive approach. In the transformation, approach is the curriculum development approach which is done by changing the assumption about the curriculum into a competency that must be mastered by students by paying attention to the problems that are occurring at this time.

\subsection{Evaluation}

Evaluation of the development of a multicultural education curriculum at Darul Hikmah Modern Islamic Boarding School Tulungagung was carried out in several ways. First, the curriculum material that was evaluated was the KMI curriculum (Kuliyatul Mualimin Al Islamiyah). Evaluations are conducted every year by bringing in scholars, teachers, foundation administrators, and experts to find out whether the curriculum is still relevant or not. If it is necessary, it must be added. If it is not necessary then it is deleted. Everything was decided in the meeting.

Second, the material of the Islamic curriculum includes evaluating Darul Hikmah Islamic Middle School, Darul Hikmah Islamic High School and Night School. The aspects that are evaluated follow the CIPP model, namely context, input, process, and product so it is called the CIPP curriculum evaluation model. But in this research, evaluation of multicultural education development refers to curriculum evaluation that focuses on aspects of processes and products. Process evaluation in developing multicultural education curriculum is curriculum evaluation activities with an emphasis on the process of curriculum implementation from beginning to end (Rusdiana, 2015).

The things needed for the evaluation of the process are the use of textbooks, places of learning, learning strategies, and learning evaluations. Assessment criteria for the evaluation of the process include students' performance in class, quality of learning implementation, personnel support, students' satisfaction with the learning process, and test standards used (Rusdiana, 2015).

Success criteria in the evaluation process are related to the impact of the curriculum on learners' behavior and learning experiences at school. Next is the evaluation of multicultural education curriculum development with a focus on product aspects. Product evaluation is understood as an evaluation activity with an emphasis on the impact of the curriculum on the acceptance of alumni in the midst of society (Peter, 2012). Data needed for product evaluation is the number of graduates and community acceptance of graduates. Assessment criteria for product evaluation include: diplomas awarded to graduates, graduate performance in the community, graduate satisfaction with its position in the community, and community satisfaction with graduate performance (Finch, 1999). Assessment 
criteria for product evaluation relate to the impact of the curriculum on the behavior and performance of graduates in the community and the world of work.

\section{Conclusions}

From this research, it can be concluded that the development of multicultural education curriculum at Darul Hikmah Modern Islamic Boarding School Tulungagung uses three foundations namely physiological foundation, sociological foundation, and psychological foundation. The implication, Darul Hikmah Modern Islamic Boarding School Tulungagung uses three approaches in developing a multicultural education curriculum. The approaches used by Darul Hikmah Modern Islamic Boarding School Tulungagung in developing its multicultural education curriculum are the contribution approach, additive approach, and transformation approach. Approaches to develop a multicultural education curriculum at Darul Hikmah Modern Islamic Boarding School Tulungagung can be done effectively and efficiently. Whereas in its evaluation, the development of multicultural education curriculum at the Darul Hikmah Modern Islamic Boarding School Tulungagung was carried out with, firstly, the curriculum material of the curriculum for which the KMI curriculum evaluation (Kuliyatul Mualimin Al Islamiyah) was carried out every year, by bringing in teachers, foundations, Kyais and experts to find out that it was still relevant or not the curriculum, it needs to be added or not decided in the meeting. Second, Islamic school curriculum material which includes evaluating Darul Hikmah Middle School, Darul Hikmah High School and Night School.

\section{REFERENCE}

[1] Abdullah, A. (2007). KURIKULUM PENDIDIKAN DI INDONESIA SEPANJANG SEJARAH (SUATU TINJAUAN KRITIS FILOSOFIS). Jurnal Pendidikan Dan Kebudayaan. https://doi.org/10.24832/jpnk.v13i66.354

[2] Aly, A. (2015). Studi Deskriptif Tentang Nilai-Nilai Multikultural Dalam Pendidikan Di Pondok Pesantren Modern Islam Assalaam. Jurnal Ilmiah Pesantren.

[3] Bahri, S. (2017). PENGEMBANGAN KURIKULUM DASAR DAN TUJUANNYA. Jurnal Ilmiah Islam Futura. https://doi.org/10.22373/jiif.v11i1.61

[4] Beane, J. A. (2015). Curriculum integration and the disciplines of knowledge. In The Routledge International Handbook of Creative Learning. https://doi.org/10.4324/97 80203817568.ch20

[5] Bogdan, R., \& Biklen, S. K. (2003). Bogdan, R. C \& Biklen, S. K. (2003). Qualitative Research for Education: An introduction to Theories and Methods (4th ed.). New York:
Pearson Education group. (pp. 110-120). Qualitative Research for Education: An Introduction to Theories and Methods.

[6] Bowen, G. A. (2009). Document analysis as a qualitative research method. Qualitative Research Journal. https://doi. org/10.3316/QRJ0902027

[7] Bustamam-ahmad, K. (2015). Educational practice : lessons to be learned from madrasah and religious. Indonesian Journal of Islam and Muslim Societies.

[8] Cahyono, H. (2017). Pendidikan Multikultural Di Pondok Pesantren. At-Tajdid.

[9] Dunne, D., \& Martin, R. (2006). Design thinking and how it will change management education: An interview and discussion. Academy of Management Learning and Education. https://doi.org/10.5465/AMLE.2006.23473212

[10] Faoziah, N., Mahfudh, H., \& Ronika, R. (2016). Religion and Multiculturalism at Pesantren Sunan Pandanaran and Mu'allimin Yogyakarta. Al-Albab.https://doi.org/10.24260 /alalbab.v5i1.352

[11] Hasan, A. B. P., \& Suwarni, E. (2012). Policies and Practices for Promoting Multicultural Awareness of Indigenous Early Childhood Education in Indonesia. International Journal of Child Care and Education Policy. https://doi.org/10.1007/ 2288-6729-6-1-63

[12] Hashim, C. N., \& Langgulung, H. (2008). Islamic Religious Curriculum in Muslim Countries: The Experiences of Indonesia and Malaysia. Bulletin of Education \& Research.

[13] Knight, G. R. (2001). The Aims of Adventist Education in Historical Perspective. Journal of Research on Christian Education.

[14] Kuswandi, I. (2014). STRATEGI PESANTREN DALAM MENCETAK MANUSIA INDONESIA MULTI-KULTUR. Jurnal Pelopor Pendidikan.

[15] Liberna, H. (2015). Peningkatan Kemampuan Berpikir Kritis Matematis Siswa Melalui Penggunaan Metode Improve pada Materi Sistem Persamaan Linear Dua Variabel. Formatif: Jurnal Ilmiah Pendidikan MIPA.

[16] Lubis, M. A., Embi, M. A., Yunus, M. M., Wekke, I. S., \& Nordin, N. M. (2009). The application of multicultural education and applying ICT on Pesantren in South Sulawesi, Indonesia. WSEAS Transactions on Information Science and Applications.

[17] Lukens-Bull, R. A. (2017). Teaching Morality: Javanese Islamic Education in a Globalizing Era. Journal of Arabic and Islamic Studies. https://doi.org/10.5617/jais.4554

[18] Lynch, J. (2017). Curriculum and assessment. In Education and Cultural Pluralism.https://doi.org/10.4324/978131539 3629

[19] Miles, M. B., \& Huberman, M. (1994). Early Steps in Analysis. In Qualitative Data Analysis: An Expanded Source Book, 2nd edition.

[20] Musyarofah, M. (2016). INTERNALISASI PESAN MULTIKULTURAL PADA ORGANISASI PESANTREN PUTRI STAIN JEMBER. INJECT (Interdisciplinary Journal of Communication). https://doi.org/10.18326/injec t.v1i2.650 
[21] Noorhayati, S. M. (2017). Pendidikan Multikultural di Pesantren (Upaya Membendung Radikalisme di Indonesia). MADANIA: JURNAL KAJIAN KEISLAMAN. https://doi.or $\mathrm{g} / 10.29300 /$ madania.v21i1.212

[22] Pring, R. (2018). Philosophical debates on curriculum, inequalities and social justice. Oxford Review of Education. https://doi.org/10.1080/03054985.2018.1409963

[23] Raihani. (2012). Report on multicultural education in pesantren. Compare.https://doi.org/10.1080/03057925.201 2.672255

[24] Rif 'atul, M., Madrasah, T., Negeri, K., \& Jombang, I. (2015). Multikulturalisme Pesantren di antara Pendidikan Tradisional dan Modern. Jurnal Studi Islam.

[25] Rusdiana, Y. S. and A. (2015). Pendidikan Multikultural, Suatu Upaya Penguatan Jati Diri Bangsa (2015th ed.; B. Asaebani, Ed.). Bandung.

[26] Saifulah, S. (2014). Dakwah Multikultural Pesantren Ngalah dalam Meredam Radikalisme Agama. ISLAMICA: Jurnal Studi Keislaman. https://doi.org/10.15642/islamica.2014.8. 2.421-446

[27] Sukmadinata, N. S. (2006). Pengembangan Kurikulum, Teori dan Praktik (1st ed.; Mukhlis, Ed.). Bandung: Remaja Rosdakarya.

[28] Syafe'i, I. (2017). Model Kurikulum Pesantren Salafiyah dalam Perspektif Multikultural. Al-Tadzkiyyah: Jurnal Pendidikan Islam. https://doi.org/10.24042/atjpi.v8i2.2121

[29] Wear, D., \& Castellani, B. (2000). The development of professionalism: Curriculum matters. Academic Medicine. https://doi.org/10.1097/00001888-200006000-00009 